\title{
Meningkatkan Kinerja Karyawan Melalui Sistim Informasi Manajemen dan Komunikasi (Studi pada Biro Pengelolaan Barang Milik Daerah Setda Provinsi Jambi)
}

\author{
Gupron \\ Dosen Fakultas Ekonomi Universitas Batanghari Jambi, Indonesia
}

\begin{abstract}
This study aims to analyze the effect of Management Information Systems and Communication on the performance of employees both partially and simultaneously at the Regional Secretariat's Regional Management Bureau of Jambi Province. The population in this study were employees of the Regional Secretariat Regional Management Bureau of Jambi Province with a number of 77. Because the population in this study was less than 100 people, in this study the sampling method used the census method. Quantitative analysis method using Path Analysis, followed by analysis of determination ( $R$ Square), partial hypothesis testing $(t$ test) and simultaneous ( $F$ test) with alpha 5 percent (0.05). Before further analysis, the classical assumption test is carried out first. Analysis tools using SPSS version 21.0 for Windows. The results showed that management and communication information systems had a positive and significant effect on the performance of employees at the Regional Secretariat's Regional Management Bureau of Jambi Province.
\end{abstract}

Keyword: Management, Communication and Performance Information Systems.

\section{PENDAHULUAN}

Teknologi informasi beberapa dekade terakhir ini telah mengalami perkembangan yang sangat pesat. Dengan berkembang dan majunya teknologi informasi tersebut, telah memacu organisasi untuk menggunakan teknologi sebagai pengolah dan penyedia informasi. Teknologi informasi dalam organisasi bisnis dewasa ini menjadi penting karena berkaitan dengan ketepatan waktu dan kebenaran penyediaan informasi yang dibutuhkan pemakai. Selain itu teknologi informasi sudah menjadi pilihan utama dalam menciptakan sistem informasi suatu organisasi yang tangguh dan mampu melahirkan keunggulan kompetitif di tengah persaingan yang semakin ketat dewasa ini. Karena dasar tersebutlah sistem informasi tidak kalah pentingnya dengan komponen-komponen sumber daya lainnya, seperti akuntansi, keuangan, manajemen operasi, marketing dan manajemen sumber daya manusia (Ali, 2010).

Sistem informasi merupakan salah satu komponen penting untuk mencapai kesuksesan suatu perusahaan atau organisasi. Sistem informasi yang diterapkan didalam organisasi adalah komponen yang menjadi bagian dari organisasi bersama dengan individu-individu di dalam organisasi untuk saling berinteraksi dan saling memanfaatkan untuk mendapatkan hasil kerja yang efektif dan efisien (Dewi, 2013). Sistem informasi manajemen (SIM) merupakan salah satu bentuk sistem informasi yang berfungsi untuk membantu para penggunannya dalam mengambil keputusan. Sistem informasi manajemen merupakan suatu sistem yang dapat membantu manajemen di dalam pengumpulan data, pengolahan serta analisis evaluasi data dan menyajikan ke dalam batas informasi yang bernilai dan akhirnya sampai pada pengambilan keputusan di mana informasi ini berguna untuk mendukung fungsi operasi manajemen (Machmud, 2013).

Adapun tujuan dari penerapan SIM secara khusus adalah untuk menyampaikan informasi kepada manager/pimpinan tentang kinerja organisasi dan lingkungannya pada waktu tertentu, pada waktu yang lalu, saat ini dan prakiraan di masa mendatang (Ali, 2010). Penerapan sistem informasi manajemen sangat penting dalam mendukung operasi manajemen sehari-hari, yang terdiri dari sumber daya sistem informasi untuk membantu perencanaan taktis, dan pengambilan keputusan, untuk mendukung perencanaan dan perumusan kebijakan oleh tingkat manajemen. Jadi jelaslah bahwa sistem informasi manajemen merupakan suatu sistem informasi yang memungkinkan pimpinan organisasi mendapatkan jumlah dan mutu, serta saat yang tepat untuk dipergunakan dalam rangka meningkatkan kinerja pegawai (Machmud, 2013). Selain itu Siagian (1994) mengemukakan dengan sistem informasi manajemen memungkinkan pimpinan memecahkan masalah-masalah yang tidak dapat dipecahkan sebelumnya. Selain itu dengan sistem informasi manajemen akan dapat mengurangi pemborosan atau in-efisiensi serta mampu meningkatkan efektifitas kerja para pegawai. (Adisetiawan, 2016) 
Selain sistem informasi manajemen, adapun faktor lain yang dapat mempengaruhi kinerja pegawai dalam suatu organisasi adalah komunikasi, hal ini dikemukakan Srimiatun dan Prihatinta, (2017) yang mengatakan bahwa dengan terjalinnya komunikasi yang baik diantara karyawan dapat menimbulkan kinerja yang lebih baik sehingga mengurangi tingkat penurunan kinerja. Selain itu Haedar, Sampetan, dan Suardi, (2017) mengungkapkan Komunikasi yang baik dapat menjadi sarana yang tepat dalam meningkatkan kinerja karyawan. Melalui komunikasi, karyawan dapat meminta petunjuk kepada atasan mengenai pelaksanaan kerja. Melalui komunikasi juga karyawan dapat saling bekerja sama satu sama lain. (Adisetiawan, 2017)

Dalam suatu organisasi makna komunikasi berperan sangat penting, pentingnya komunikasi dalam perusahaan adalah dimana dalam melakukan pekerjaan diantara sesama karyawan memerlukan komunikasi yang efektif agar dapat dimengerti pesan-pesan tentang pekerjaan. Suatu pesan tentang pekerjaan yang akan disebar luaskan maka pastilah informasi tersebut harus berjalan mengikuti suatu alur dari pimpinan sampai kepada para karyawannya ataupun sebaliknya dan juga diantara karyawan, komunikasi yang terjadi didalam suatu organisasi nantinya juga akan mempengaruhi kegiatan organisasi, seperti efisiensi kerja, peningkatan kinerja, kepuasan karyawan dan lainnya (Haedar, Sampetan, dan Suardi, 2017). Penelitian ini dilakukan dengan tujuan untuk menganalisis: 1) Pengaruh sistem informasi manajemen terhadap kinerja; 2) Pengaruh komunikasi terhadap kinerja; dan 3) Pengaruh sistem informasi maajemen dan komunikasi secara simultan terhadap kinerja.

\section{Tinjauan Pustaka}

\section{Sistem Informasi Manajemen}

Sistem informasi manajemen adalah suatu sistem berbasis computer yang menyediakan informasi bagi beberapa pemakai dengan kebutuhan serupa. Para pemakai biasanya membentuk suatu entitas organisasi formal/perusahaan/institusi atau sub unit di bawahnya. Informasi menjelaskan perusahaan atau salah satu sistem utamanya mengenai apa yang telah terjadi di masa lalu, apa yang sedang terjadi sekarang dan apa yang mungkin terjadi di masa depan. Informasi terseut tersedia dalam bentuk laporan laporan periodic, laporan khusus, dan output dari simulasi matematika. Output informasi digunakan oleh manajer maupun non manajer dalam perusahaan saat mereka membuat keputusan untuk memecahkan masalah (McLeod dan Schell, 2007). Menurut Ali (2010) sistem informasi manajemen adalah suatu wilayah sistem informasi yang dibuat untuk mendukung informasi yang dibutuhkan untuk pengambilan keputusan oleh manajer. Davis (2002) menyatakan bahwa sistem informasi manajemen adalah sebuah sistem manusia/mesin yang terpadu untuk menyajikan informasi guna mendukung fungsi operasi manajemen dan pengambilan keputusan dalam sebuah organisasi. Beberapa peneliti telah menggunakan beberapa pengukuran untuk mengukur sistem informasi manajemen menurut DeLone and McLean (2003) menggunakan pengukuranpengukuran sebagai berikut: a) kualitas sistem; b) kualitas informasi; dan c) kualitas layanan.

\section{Komunikasi}

Komunikasi adalah proses dengan mana informasi dan arti atau makna di transfer dari sender kepada receiver (Colquitt, LePine, dan Wesson, 2011). Kebanyakan pekerjaan yang dilakukan dengan dalam suatu tim diselesaikan secara independent, saling bergantung dan menyangkut komunikasi di antara anggota. Karena itu efektivitas komunikasi memainkan peran penting dalam menentukan apakah terdapat keungtungan atau kerugian dalam proses komunikasi. Komunikasi menunjukan pada proses dengan mana informasi di kirimkan dan di pahami diantara dua orang atau lebih (McShane dan Glinov, 2010). Penekanan pada kata dipahami karena mengirimkan arti yang di maksudkan sender adalah esensi komunikasi yang baik. Komunikasi adalah pertukaran informasi antara sender dan receiver, dan menarik kesimpulkan sebagai persepsi tentang makna sesuatu antara individual yang terlibat. Juga dikatakan sebagai pertukaran interpersonal dari informasi dan pengertian (Kreitner dan Kinicki, 2010). Sedangkan menurut Greenberg dan Baron (2003), komunikasi adalah proses dengan mana orang, kelompok atau organisasi sebagai the sender mengirimkan beberapa tipe informasi sebagai the message kepada orang, kelompok atau organisasi lain sebagai the receiver. Komunikasi organisasi dapat di artikan sebagai pertunjukan dari penafsiran pesan diantara unit-unit komunikasi yang merupakan bagian dari suatu organisasi tertentu. Indikator-indikator yang dapat menunjang atau dapat dikatakan sebagai pengukuran dari komunikasi dapat dilihat melalui arah 
aliran komunikasi sebagai berikut: 1) komunikasi kebawah; 2) komunikasi keatas; 3) komunikasi horizontal; dan 4) komunikasi lintas saluran.

\section{Kinerja}

Kinerja merupakan perilaku nyata yang ditampilkan setiap orang sebagai prestasi kerja yang dihasilkan oleh karyawan sesuai dengan perannya dalam organisasi. Kinerja karyawan merupakan suatu hal yang sangat penting dalam upaya organisasi untuk mencapai tujuan (Rivai dan Sagala, 2009). Sedangkan menurut Hasibuan (2009) mendefinisikan kinerja sebagai suatu hasil kerja yang dicapai seseorang dalam melaksanakan tugas-tugas yang dibebankan kepadanya yang didasarkan atas kecakapan, pengalaman, kesungguhan serta waktu. Istilah kinerja berasal dari kata job performance atau actual performance (prestasi kerja atau prestasi sesungguhnya yang dicapai seseorang) yaitu hasil kerja secara kualitas dan kuantitas yang dicapai oleh seorang pegawai dalam melaksanakan tugasnya sesuai dengan tanggung jawab yang diberikan kepadanya (Mangkunegara, 2014). Pengertian tersebut memberikan pemahaman bahwa kinerja merupakan suatu perbuatan atau perilaku seseorang dalam pelaksanaan tugasnya, yang dapat diamati dan dinilai oleh orang lain. Lebih lanjut Mangkunegara (2014) menyatakan bahwa pada umumnya kinerja dibedakan menjadi dua, yaitu kinerja individu dan kinerja organisasi. Kinerja individu adalah hasil kerja pegawai baik dari segi kualitas maupun kuantitas berdasarkan standar kerja yang telah ditentukan, sedangkan kinerja organisasi adalah gabungan dari kinerja individu dan kinerja kelompok. Menurut Rivai dan Sagala (2009) adapun aspek-aspek yang dinilai untuk mengukur kinerja seseorang dapat dikelompokkan sebagai berikut: 1) Kemampuan teknis; 2) Kemampuan konseptual; dan 3) Kemampuan hubungan interpersonal.

\section{Kerangka Berpikir}

Beberapa kajian teori maka teori yang menjadi acuan pada riset ini berdasarkan kasus, objek dan unit analisis riset, maka teori yang digunakan pada riset ini adalah sebagai berikut:

1) Kinerja (Y) menurut Rivai dan Sagala (2009) dengan dimensi/indikator: 1) Kemampuan teknis; 2) Kemampuan konseptual; dan 3) Kemampuan hubungan interpersonal.

2) Sistem informasi manajemen $\left(X_{1}\right)$ menurut DeLone and McLean (2003), dengan dimensi/indikator: a) kualitas sistem; b) kualitas informasi; dan c) kualitas layanan.

3) Komunikasi $\left(\mathrm{X}_{2}\right)$ dengan dimensi/indikator: a) komunikasi kebawah; b) komunikasi keatas; c) komunikasi horizontal; dan d) komunikasi lintas saluran.

Beberapa kajian penelitian terdahulu berdasarkan kasus, objek dan unit analisis riset, maka riset terdahulu yang menjadi acuan untuk riset ini adalah sebagai berikut:

1) Sistem informasi manajemen $\left(\mathrm{X}_{1}\right)$ berpengaruh terhadap Kinerja $(\mathrm{Y})$, berdasarkan hasil riset: Dewi, (2013); Koniyo, dan Latief (2011); Machmud, (2013); dan Widodo, Handayani, dan Saifi (2011). Dimana sistem infomasi berpengaruh positif dan signifikan terhadap kinerja baik secara parsial maupun secara simultan.

2) Komunikasi $\left(\mathrm{X}_{2}\right)$ berpengaruh terhadap Kinerja (Y), berdasarkan hasil riset: Alam (2014); Haedar, Sampetan, dan Suardi, (2017); Samodro dan Lestari (2018); dan Srimiatun dan Prihatinta, (2017), dimana komunikasi berpengaruh positif dan seignifikan terhadap kinerja baik secara parsial maupun secara simultan.

Kajian teori dan riset terdahulu dan berdasrkan tujuan riset maka rerangka riset ini adalah seperti di bawah ini. 


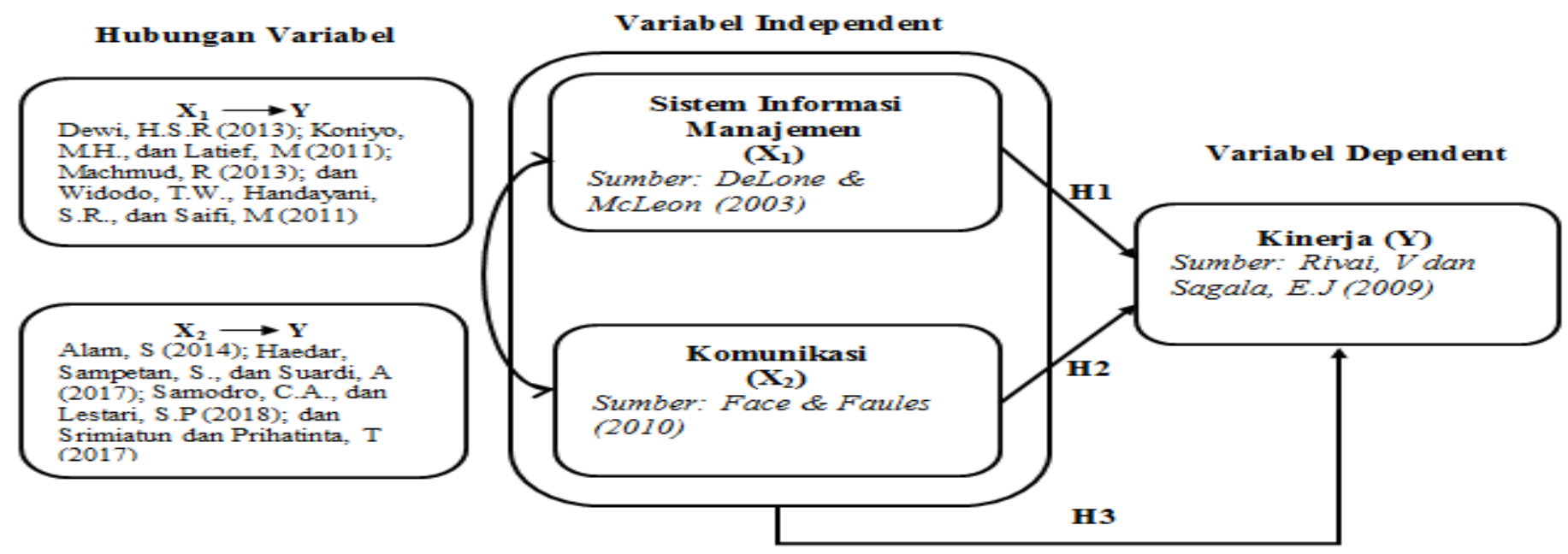

Gambar 1

Kerangka Pemikiran

Berdasarkan tujuan penelitian dan tinjauan teori maka Hipotesis penelitian adalah:

1) Sistem informasi manajemen berpengaruh terhadap kinerja;

2) Komunikasi berpengaruh terhadap kinerja; dan

3) Sistem informasi manajemen dan kmunikasi berpengaruh terhadap Kinerja.

\section{METODE PENELITIAN}

Penelitian ini dilakukan dengan menggunakan pendekatan kuantitatif asosiatif dengan metode survey dan menggunakan teknik path Analysis. Path analysis digunakann untuk menganalisis pola hubungan antar variabel dengan tujuan untuk mengetahui pengaruh langsung maupun tidak langsung seperangkat variabel bebas (eksogen) terhadap variabel terikat (endogen) (Riduwan dan Kuncoro, 2013). Populasi dalam penelitian ini adalah pegawai pada Biro Pengelolaan Barang Milik Daerah Setda Provinsi Jambi dengan jumlah populasi 77 pegawai. Dikarenakan jumlah populasi dalam penelitian ini kurang dari 100 orang maka dalam penelitian ini metode pengambilan sampel menggunakan metode sensus. Sebelum analisis, dilakukan uji instrumen kuesioner dengan uji validitas dan reliabilitas serta uji asumsi klasik dengan uji normalitas, dan heterokedastisitas. Path analysis merupakan salah satu alat analisis yang dikembangkan (Ali dan Limakrisna, 2013). Wright mengembangkan metode untuk mengetahui pengaruh langsung dan tidak langsung dari suatu variable, dimana terdapat variable yang memberikan pengaruh (eksogenus variables) dan variable yang dipengaruhi (endogenus variables).

\section{HASIL DAN PEMBAHASAN}

Statistik deskriptif yang digunakan adalah nilai rata-rata (mean), nilai yang sering muncul pada jawaban responden (modus), nilai tengah (median), simpangan baku (standar deviasi) serta varians sampel. Adapun hasil statistik deskriptif dalam penelitian dengan menggunakan alat bantu SPSS 21.0 sebagai berikut:

Tabel 1

Statistik Deskriptif Variabel Penelitian

\begin{tabular}{|ll|r|r|r|}
\hline & & X1_SIM & X2_Komunikasi & \multicolumn{1}{|c|}{ Y_Kinerja } \\
\hline $\mathrm{N}$ & Valid & 77 & 77 & 77 \\
Mean & Missing & 0 & 0 & 0 \\
Std. Error of Mean & 3.3385 & 3.3660 & 3.4298 \\
Median & .03290 & .03085 & .02765 \\
Mode & 3.4000 & 3.3636 & 3.4545 \\
Std. Deviation & 3.40 & 3.55 & 3.64 \\
& & .28873 & .27072 & .24261
\end{tabular}

Meningkatkan Kinerja Karyawan Melalui Sistim Informasi Manajemen dan Komunikasi (Studi pada Biro Pengelolaan Barang Milik Daerah Setda Provinsi Jambi) 


\begin{tabular}{|l|r|r|r|} 
Variance & .083 & .073 & \\
Range & 1.20 & 1.27 & .059 \\
Minimum & 2.67 & 2.64 & 1.00 \\
Maximum & 3.87 & 3.91 & 2.82 \\
Sum & 257.07 & 259.18 & 3.82 \\
\hline
\end{tabular}

Sumber: data olahan

Sebelum menilai kriteria variabel penelitian terlebih dahulu akan dibuat kriteria penilaian skor. Dengan jumlah skor tertinggi adalah 5, dan jumlah skor terendah adalah 1. Klasifikasi skor jawaban responden untuk variabel penelitian dapat digambarkan dalam tahapan bobot skor dengan rentang skor 5 $1 / 5=0,8$, sebagai berikut :

\begin{tabular}{l|lrr|rrr|rr|} 
Sangat Buruk & & Buruk & Cukup Baik & Baik & Sangat Baik \\
1 & 1,8 & & 2,6 & 3,4 & 4,2 & 5
\end{tabular}

\section{Deskripsi Variabel Sistem Informasi Manajemen $\left(X_{1}\right)$}

Hasil deskriptif variabel SIM seperti yang tampak pada Tabel 1 di atas diperoleh nilai rata rata sebesar 3,3385 termasuk pada range 2,6 - 3,4 berada pada kriteria Cukup Baik. Hal ini menunjukan bahwasanya sistem informasi manajemen yang ada saat ini sudah berlangsung cukup baik, baik itu dari kualitas sistem, kualitas informasi, maupun kualitas pelayanan. Sehingga sangat membantu sekali bagi pegawai dalam melaksanakan tugas pokok dan fungsinya.

\section{Deskripsi Variabel Komunikasi $\left(\mathrm{X}_{2}\right)$}

Hasil deskriptif variabel komunikasi seperti yang tampak pada Tabel 1 di atas diperoleh nilai rata rata sebesar 3,3660 termasuk pada range 2,6 - 3,4 berada pada kriteria Cukup Baik. Yang menjelaskan bahwasanya komunikasi yang berlangsung pada Biro Pengelolaan Barang Milik Daerah Setda Provinsi Jambi telah berlangsung dengan cukup baik, baik itu berupa komunikasi kebawah, komunikasi keatas, komunikasi horizontal, maupun komunikasi lintas saluran. Sehingga mampu mendorong pegawai untuk dapat bekerja dengan baik.

\section{Deskripsi Variabel Kinerja (Y)}

Hasil deskriptif variabel kinerja seperti yang tampak pada Tabel 1 di atas diperoleh nilai rata rata sebesar 3,4298 termasuk pada range 3,4 - 4,2 berada pada kriteria Baik. Yang menjelaskan bahwasanya kinerja pegawai pada Biro Pengelolaan Barang Milik Daerah Setda Provinsi Jambi sudah berlangsung dengan baik.

\section{Uji Asumsi Klasik}

Tabel 2

Coefficients regression

\begin{tabular}{|c|c|c|c|c|c|c|}
\hline \multirow{2}{*}{\multicolumn{2}{|c|}{ Model }} & \multicolumn{2}{|c|}{ Unstandardized Coefficients } & \multirow{2}{*}{$\begin{array}{c}\text { Standardized Coefficients } \\
\text { Beta }\end{array}$} & \multirow[t]{2}{*}{$\mathrm{t}$} & \multirow[t]{2}{*}{ Sig. } \\
\hline & & $\mathrm{B}$ & Std. Error & & & \\
\hline \multirow{3}{*}{1} & (Constant) & 11.471 & 2.600 & & 4.412 & .000 \\
\hline & X1_SIM & .391 & .058 & .634 & 6.695 & .000 \\
\hline & X2_Komunikasi & .181 & .085 & .202 & 2.131 & .036 \\
\hline
\end{tabular}

Sumber: data olahan 


\section{Gambar 2}

\section{Hasil Struktur Path Analysis}

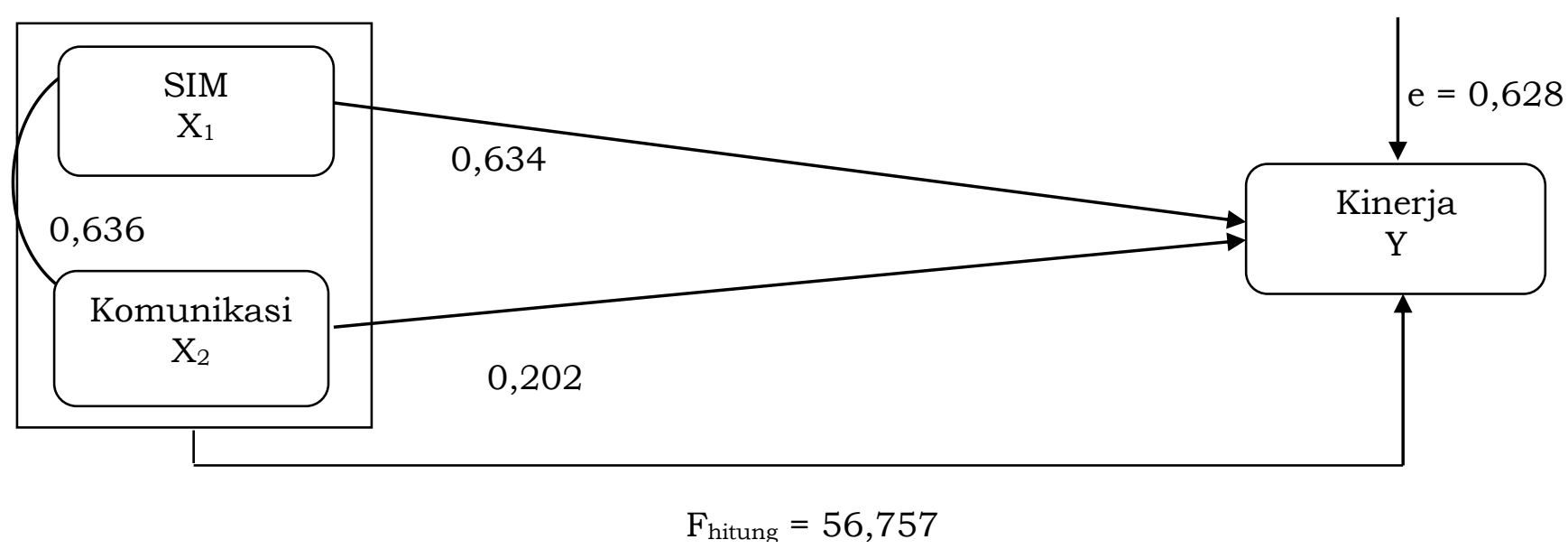

Sebelum melangkah ke pengujian hipotesis, terlebih dahulu harus melalui perhitungan persyaratan analisis. Pengujian persyaratan analisis haruslah terpenuhinya asumsi klasik. Untuk mendapatkan nilai pemeriksa yang efisien dan tidak bias atau BLUE (Best Linear Unbias Estimator) dari satu persamaan regresi berganda dengan metode kuadrat terkecil (least square), maka perlu dilakukan pengujian untuk mengetahui model regresi yang dihasilkan memenuhi persyaratan asumsi klasik. Dalam penelitian ini akan di kemukakan uji asumsi klasik yang umum digunakan, yaitu Uji Normalitas Uji Muktikolinearitas dan Uji Heterokedastisitas. Hasil uji yang dilakukan dengan menggunkan bantuan SPSS 21.0 sebagai alat bantu dalam penelitian ini diperoleh hasil bahwasanya data dalam penelitian ini berdistribusi normal, hal ini dibuktikan dari hasil nilai signifikansi (Asymp. Sig. 2-tailed) lebih besar dari 0,05, yaitu $(0,254>0,05)$ sehingga dapat disimpulkan bahwa data dalam penelitian ini berdistribusi normal. Kemudian dari hasil uji heterokedastisitas diketahui scatterplots terlihat bahwa titik-titik menyebar secara acak serta tresebar baik diatas maupun dibawah angka 0 pada sumbu Y. hal ini dapat disimpulkan bahwa tidak terjadi heterokedastisitas pada model regresi, sehingga model layak dipakai untuk memprediksi Penggunaan jasa akomodasi berdasarkan masukan variabel independent. Berdasarkan dari hasil uji asumsi tersebut maka telah terpenuhinya Persyaratan untuk dilakukannya pengujian selanjutnya. Hasil penelitian ini dirangkum seperti Tabel 2 di bawah ini dengan koefisien variabel SIM $\left(\mathrm{X}_{1}\right)$ dan komunikasi $\left(\mathrm{X}_{2}\right)$ adalah $\left(\mathrm{Pyx}_{1}=0,634\right.$ dan $\left.\mathrm{Pyx}_{2}=0,202\right)$ dan korelasi antar variabel $\mathrm{X}_{1}$ dan $\mathrm{X}_{2}$ adalah 0,636 yang dapat disajikan seperti gambar 2.

Tabel 2 di atas diperoleh hasil koefisien analisis jalur: $Y=\rho \mathrm{yx}_{1} \cdot \mathrm{X}_{1}+\rho \mathrm{yx}_{2} . \mathrm{X}_{2}+\mathrm{e}=0,634 . \mathrm{X}_{1}+$ $0,202 . X_{2}+0,628$. Nilai koefisien jalur variabel sistem informasi manajamen (SIM) terhadap variabel kinerja adalah sebesar 0,634. Nilai koefisien jalur variabel komunikasi terhadap variabel kinerja adalah sebesar 0,202. Koefisien bernilai positif artinya SIM dan komunikasi berpengaruh positif terhadap kinerja.

Untuk melihat pengaruh langsung dan tidak langsung, dapat dilihat pada tabel 3 berikut ini:

Tabel 3

Rangkuman Koefisien Jalur Sistem Informasi Manajemen dan Komunikasi Terhadap Kinerja

\begin{tabular}{|l|r|r|r|r|r|}
\hline \multirow{2}{*}{ Variabel } & \multirow{2}{*}{ Langsung } & \multicolumn{2}{c|}{ Tidak Langsung } & \multirow{2}{*}{ Sub Total } & \multicolumn{1}{c|}{ Total } \\
\cline { 3 - 6 } & & $\mathbf{X}_{\mathbf{1}}$ & $\mathbf{X}_{\mathbf{2}}$ & \\
\hline $\mathrm{X}_{1}$ SIM & $40,20 \%$ & & $8,15 \%$ & $8,15 \%$ & $48,35 \%$ \\
\hline $\mathrm{X}_{2 \_ \text {Komunikasi }}$ & $4,08 \%$ & $8,15 \%$ & & $8,15 \%$ & $12,23 \%$ \\
\hline \multicolumn{3}{|c|}{ Pengaruh $\mathbf{X}_{\mathbf{1}}, \mathbf{X}_{\mathbf{2}}$} \\
\hline
\end{tabular}

Sumber: data olahan

Hasil analisis jalur yang dilakukan diperoleh pengaruh langsung sistem informasi manajemen terhadap kinerja sebesar 40,20\%, komunikasi terhadap kinerja sebesar 4,08\% dan total pengaruh sistem 
informasi manajemen dan komunikasi terhadap kinerja secara langsung maupun tidak langsung sebesar 60,58. Nilai tersebut menjelaskan nilai koefisien determinasi $\mathrm{R}^{2}$ Square Seperti yang tampak pada tabel berikut.

Tabel 4

Model summary

\begin{tabular}{|c|c|c|c|c|}
\hline Model & $\mathrm{R}$ & R Square & Adjusted R Square & Std. Error of the Estimate \\
\hline 1 & $.778^{\mathrm{a}}$ & .605 & .595 & 1.6990 \\
\hline
\end{tabular}

Sumber: data olahan

Nilai $\mathrm{R}$ sebesar 0,778 menunjukan korelasi ganda (sistem informasi manajemen dan komunikasi) dengan kinerja. Dengan mempertimbangkan variasi Nilai R Square sebesar 0,605, memiliki makna besarnya peran atau kontribusi variabel sistem informasi manajemen dan komunikasi mampu menjelaskan variabel kinerja pegawai sebesar $60,5 \%$. Sedangkan sisanya sebesar 39,5\% dipengaruhi oleh variabel lain yang tidak termasuk dalam model ini.

\section{Uji Hipotesis}

\section{Uji Parsial (Uji t)}

Pengujian pengaruh parsial bertujuan untuk menuji apakah masing-masing variabel bebas berpengaruh secara signifikan terhadap variabel terikat secara parsial dengan $\propto=0,05$ dan penerimaan atau penolakan hipotesis. Uji parsial (Uji t) untuk menjawab hipotesis satu dan dua dari penelitian ini.

Tabel 5

Hasil Uji t (Parsial)

\begin{tabular}{clcc}
\hline No & Variabel Bebas & $\mathrm{t}_{\text {hitung }}$ & Sig. \\
\hline 1 & $\mathrm{X}_{1}$ Sistem Informasi Manajemen & 6,695 & 0.000 \\
2 & $\mathrm{X}_{2 \_ \text {Komunikasi }}$ & 2,131 & 0.036 \\
\hline
\end{tabular}

Sumber: data olahan

\section{1) Pengaruh Sistem Informasi Manajemen Terhadap Kinerja}

Dari hasil output SPSS seperti yang tampak pada Tabel 5 yang dilakukan diperoleh angka nilai $t$ hitung variabel $\mathrm{X}_{1}$ lebih besar dari nilai t tabel $(6,695>1,665)$, dengan tingkat signifikansi sebesar 0,000, dikarenakan angka taraf signifikansi lebih $<0,05(0,000<0,05)$ maka dapat disimpulkan bahwa SIM berpengaruh terhadap kinerja. Berdasarkan dari penjelasan tersebut oleh karena itu $\mathrm{H}_{0}$ ditolak dan $\mathrm{H}_{1}$ diterima, artinya SIM berpengaruh terhadap kinerja pegawai.

Besarnya pengaruh langsung SIM terhadap kinerja pegawai adalah 40,20\%. Sedangkan besarnya pengaruh tidak langsung SIM melalui komunikasi terhadap kinerja adalah 8,15\%. Dengan demikian pengaruh total (langsung dan tidak langsung) variabel SIM terhadap kinerja adalah 48,35\%. Berdasarkan hipotesis penelitian yang dilakukan menyatakan bahwa SIM berpengaruh terhadap kinerja pegawai terbukti. Hasil penelitian ini menunjukan hasil yang sama dengan penelitian yang dilakukan oleh Machmud, (2013), Koniyo dan Latief (2011), dan Widodo, Handayani, dan Saifi (2011) yang mengemukakan bahwasanya sistem informasi manajemen yang baik akan mampu meningkatkan kinerja pegawai dalam melaksanakan tugas pokok dan fungsinya. Penerapan sistem informasi manajemen sangat penting dalam mendukung operasi manajemen sehari-hari, yang terdiri dari sumber daya sistem informasi untuk membantu perencanaan taktis, dan pengambilan keputusan, untuk mendukung perencanaan dan perumusan kebijakan oleh tingkat manajemen. Jadi jelaslah bahwa sistem informasi manajemen merupakan suatu sistem informasi yang memungkinkan pimpinan organisasi mendapatkan jumlah dan mutu, serta saat yang tepat untuk dipergunakan dalam rangka meningkatkan kinerja pegawai (Machmud, 2013). Selain itu Siagian (1994) mengemukakan dengan sistem informasi manajemen memungkinkan pimpinan memecahkan masalahmasalah yang tidak dapat dipecahkan sebelumnya. Selain itu dengan sistem informasi manajemen akan dapat mengurangi pemborosan atau in-efisiensi serta mampu meningkatkan efektifitas kerja para pegawai. 
Dari hasil output SPSS sperti yang tampak pada Tabel 5 yang dilakukan diperoleh angka nilai t hitung variabel $\mathrm{X}_{2}$ lebih besar dari nilai $\mathrm{t}$ tabel $(2,131>1,665)$, dengan tingkat signifikansi sebesar 0,036 , dikarenakan angka taraf signifikansi lebih $<005(0,036<0,05)$ maka dapat disimpulkan bahwa komunikasi berpengaruh terhadap kinerja. Berdasarkan dari penjelasan tersebut oleh karena itu $\mathrm{H}_{0}$ ditolak dan $\mathrm{H}_{1}$ diterima, artinya komunikasi berpengaruh terhadap kinerja pegawai. Besarnya pengaruh langsung komunikasi terhadap kinerja pegawai adalah 4,08\%. Sedangkan besarnya pengaruh tidak langsung komunikasi melalui SIM terhadap kinerja adalah 8,15\%. Dengan demikian pengaruh total (langsung dan tidak langsung) variabel komunikasi terhadap kinerja adalah 12,23\%. Berdasarkan hipotesis penelitian yang dilakukan menyatakan bahwa komunikasi berpengaruh terhadap kinerja pegawai terbukti. Hasil penelitian ini menunjukan hasil yang sama dengan penelitian yang dilakukan oleh Srimiatun dan Prihatinta (2017), Samodro dan Lestari (2018), Alam (2014), dan Haedar, Sampetan, dan Suardi (2017) dimana hasil penelitian mengemukakan jika komunikasi yang ada dalam suatu organisasi dapat erlangsung dengan baik, maka hal ini akan diikuti pula dengan semakin baiknya hasil kerja yang diberikan oleh pegawai dalam organisasi.

Komunikasi dalam dunia kerja adalah faktor yang sangat penting bagi perusahaan, karena didalam perusahaan komunikasi menjadi salah satu kunci keberhasilan perusahaan. Jika komunikasi tidak berjalan dengan baik, maka akan sering terjadi kesalah pahaman antar bagian/unit ataupun interpersonal dalam perusahaan, atau sering disebut dengan miss communication. Interpersonal relation antar karyawan adalah cara perusahaan untuk mempererat hubungan interpersonal antar karyawan, agar tujuan perusahaan dapat tercapai. Komunikasi merupakan hal yang paling penting dan harus terjadi antara atasan dan bawahan maupun sesame karyawan dalam suatu organisasi. Komunikasi yang baik dan efektif dapat membuat kinerja pegawai menjadi lebih baik, karena pada dasarnya sebagai sumber daya manusia yang membutuhkan sesuatu untuk dapat memacu keinginan mereka untuk dapat bekerja dengan giat sehingga mereka mampu meningkatkan kreativitas dan semangat kerja sesuai dengan batas kemampuan masing-masing (Srimiatun dan Prihatinta, 2017).

\section{Uji Simultan (Uji F)}

Untuk menjawab hipotesis ketiga bahwa sistem informasi manajemen (SIM) dan komunikasi berpengaruh terhadap kinerja secara simultan dapat di lihat dari Tabel 12 dibawah ini.

Tabel 6

Hasil uji F secara simultan

\begin{tabular}{llrrrrr}
\hline Model & & Sum of Squares & df & Mean Square & F & Sig. \\
\hline \multirow{2}{*}{1} & Regression & 327.667 & 2 & 163.834 & 56.757 & $.000^{\mathrm{b}}$ \\
& Residual & 213.606 & 74 & 2.887 & & \\
& Total & 541.273 & 76 & & & \\
\hline
\end{tabular}

Sumber: data olahan

\section{3) Pengaruh Lingkungan Kerja dan Karkateristik Pekerjaan Secara Simultan Terhadap Kinerja.}

Uji Anova atau $F$ test seperti yang tampak pada Tabel 6 dengan diperoleh nilai $F_{\text {hitung }}$ sebesar 56,757 dengan tingkat probabilitas $p$-value sebesar 0,000 , dikarenakan nilai $F_{\text {hitung }}>F_{\text {tabel }}(56,757>3,12)$ dan angka taraf signifikansi jauh lebih $<0,05(0,000<0,05)$ maka dapat disimpulkan variabel SIM dan komunikasi secara bersama-sama berpengaruh secara signifikan terhadap variabel kinerja pegawai (Y). Berdasarkan penjelasan tersebut maka $\mathrm{H}_{0}$ ditolak dan $\mathrm{H}_{1}$ diterima, artinya hal ini membuktikan bahwa variabel SIM dan komunikasi secara bersama-sama berpengaruh secara signifikan terhadap variabel kinerja (Y). Dengan demikian hipotesis ketiga diterima.

\section{SIMPULAN}

Sistem informasi manajemen berpengaruh positive dan signifikan terhadap kinerja pegawai. Semakin baik sistem informasi manajemen yang ada maka akan semakin baik pula kinerja karyawannya; komunikasi berpengaruh positive dan signifikan terhadap kinerja karaywan. Semakin baik komunikasi yang berlangsung, maka akan semakin baik pula kinerja karyawannya; Sistem informasi manajemen dan 
komunikasi secara bersama-sama berpengaruh positive dan signifikan terhadap kinerja karaywan. Artinya semakin baik sistem informasi manajemen yang ada, serta di dukung pula dengan proses komunikasi yang baik antara sesame karyawan ataupun dengan atasan, maka akan semakin baik pula kinerja karaywan dalam melaksanakan tugas pokok dan fungsinya.

\section{DAFTAR PUSTAKA}

Adisetiawan, R., 2014, Performance Mahasiswa Fakultas Ekonomi Universitas Batanghari, Jurnal Ilmiah Universitas Batanghari, 14(3), 1-10

Adisetiawan, R., 2016, Faktor yang Mempengaruhi Lulusan SMA dalam Memilih Fakultas Ekonomi Universitas Batanghari, Jurnal Ilmiah Universitas Batanghari, 16(3), 1-11

Alam, S. 2014. Pengaruh Komunikasi, Motivasi, dan Disiplin Kerja Terhadap Kinerja Pegawai Lembagai Penajamin Mutu Pendidikan. e-Jurnal Katalogis, Volume 2, Nomor 1.

Ali, Hapzi. 2010. Sistem Informasi Manajemen Berbasis Teknologi Informasi. Yogyakarta: Hasta Cipta Mandiri.

Ali, Hapzi, H.,dan Limakrisna, N, 2013. Research Methodology. Edisi 1, Cet. 1, Deepublish, Yogyakarta.

Colquitt, Jason A., LePine, Jeffery A., and Wesson, Michael J. 2011. Organizational Behavior. New York: McGraw-Hill.

Davis. 2002. Sistem Informasi Manajemen. Jakarta: Pustaka Binaman Pressindo.

DeLone and McLean. 2003. The DeLone and McLean Model of Information Systems Success: A Ten-Year Update. Journal of Management Information System, Vol. 19, No. 4.

Dewi, H.S.R. 2013. Analisis Pengaruh Sistem Infomasi Manajemen Terhadap Efektivitas Kerja Pegawai Pada Bidang Sumber Daya Kesehatan Dinas Kesehatan Provinsi Jawa Barat. Tesis Universitas Pasundan.

Greenberg, Jerald., and Baron, Robert A. 2003. Behavior in Organizations. New Jersey: Pearson Education, Inc.

Haedar, Sampetan, S., dan Suardi, A. 2017. Pengaruh Motivasi dan Komunikasi Terhadap Kinerja Karywan PT. Finansia Multi Finance Cabang Palopo. Prosiding Seminar Nasional, Volume 3, Nomor 1.

Hasibuan, M.S.P. 2009. Manajemen Sumber Daya Manusia. Jakarta: Bumi Aksara.

Koniyo, M.H., dan Latief, M. 2011. Analisis Pengaruh Sistem Informasi Manajemen Terhadap Kinerja Layanan Administrasi Akademik Pada Universitas Negeri Gorontalo. Jurnal Penelitian dan Pendidikan, Volume 8, Nomor 2.

Kreitner, Robert., and Kinicki, Angelo. 2010. Organizational Behavior. New York: McGraw-Hill.

Machmud, R. 2013. Hubungan Sistem Informasi Manajemen dan Pelayanan Dengan Kinerja Pegawai Pada Rutan Makasar. Jurnal Capacity STIE AMKOP Makassar, Vol. 9, No. 1.

Mangkunegara, A.P. 2014. Perencanaan dan Pengembangan Sumber Daya Manusia. Bandung: Refika Aditama.

McLeod, R., dan Schell. 2007. Sistem Informasi Manajemen. Jakarta: PT. Indeks.

McShane, Steven L., and Von Glinov, Mary Ann. 2010. Organizational Behavior. New York: McGrawHill.

Riduwan dan Kuncoro E.A. 2013. Cara menggunakan dan memakai Path Analysis (Analisis Jalur). Bandung: Alfabeta.

Rivai, V dan Sagala, E.J. 2009. Manjemen Sumber Daya Manusia Untuk Perusahaan Dari Teori Ke Praktik. Jakarta: RajaGrafindo.

Samodro, C.A., dan Lestari, S.P. 2018. Pengaruh Komunikasi Atasan Bawahan Terhadap Kinerja Karyawan Koperasi BMT Fosilatama. Jurnal Egaliter, Vol. 1, No. 2.

Siagian, S.P. 1994. Pengembangan Sumber Daya Insani. Jakarta: Gunung Agung.

Sudirman S., dan Alhudhori, M., 2018, Analisis Sektor Unggulan dalam Meningkatkan Perekonomian dan Pembangunan Wilayah Provinsi Jambi, JMAS (Jurnal Manajemen dan Sains), 3(1), 94-107

Srimiatun dan Prihatinta, T. 2017. Pengaruh Komunikasi dan Konflik Terhadap Kinerja Karyawan Tenaga Kependidikan Politeknik Negeri Madiun. Epicheirisi, Volume 1, Nomor 1. 
Widodo, T.W., Handayani, S.R., dan Saifi, M. 2011. Pengaruh Aplikasi Sistem Informasi Manajemen (SIM) Terhadap Kinerja Karyawan (Studi Kasus pada Usaha Kecil Menengah Bidang Usaha Warnet di Kota Malang). Jurnal Profit Volume 7, No.1. 